\title{
Morphological analysis of sulfated Ca-based sorbents under conditions corresponding to oxy-fuel fluidized bed combustion
}

\author{
M. de las Obras-Loscertales, A. Rufas, L.F. de Diego*, F. García-Labiano, P. Gayán, A. Abad, J. \\ Adánez \\ Department of Energy and Environment, Instituto de Carboquímica (ICB-CSIC) \\ Miguel Luesma Castán 4, 50018, Zaragoza, Spain \\ * Corresponding author: ldediego@icb.csic.es; \\ Phone: + 34976733 977; Fax: +34 976733318
}

\begin{abstract}
The use of Ca-based sorbents in circulating fluidized beds (CFB) allows the in-situ desulfurization in oxy-fuel combustion processes. The sulfation process involves important changes in the sorbent morphology, which could vary depending on the operating conditions and be different to those observed in conventional air combustion. This work analyzes the morphological variations observed during limestone and dolomite sulfation at typical oxy-fuel combustion conditions (high $\mathrm{CO}_{2}$ concentration, higher temperatures than in air combustion) in CFB combustors (long reaction times). Sulfated samples prepared in a thermogravimetric analyzer were analyzed by Scanning Electron Microscope (SEM). The space limitations due to the higher molar volume of $\mathrm{CaSO}_{4}$ compared to $\mathrm{CaO}$ in the external surface of the particles make that the $\mathrm{CaSO}_{4}$ product layer trend to grow outwards to form a honeycomb-shaped structure. This structure appeared for limestone at both calcining and non-calcining conditions. A strong effect of the $\mathrm{CaSO}_{4}$ sintering phenomenon was observed at temperatures above $950{ }^{\circ} \mathrm{C}$. Moreover, the honeycomb structure was never observed working with dolomite in spite of the high sulfation conversions reached with this sorbent.
\end{abstract}


keywords: $\mathrm{CO}_{2}$ capture, oxy-fuel combustion, fluidized bed, Ca-based sorbent, desulfurization.

\section{INTRODUCTION}

Oxy-fuel combustion is a carbon capture technological option which consists of burning the fuel with a mix of pure oxygen and a $\mathrm{CO}_{2}$-rich recycled flue gas. In this way, the flue gas leaving the combustor is mainly composed of $\mathrm{CO}_{2}$ and $\mathrm{H}_{2} \mathrm{O}$ and thus a highly $\mathrm{CO}_{2}$ concentrated stream can be obtained after steam condensation in order to be subsequently transported and stored.

There are two types of boilers to burn coal in oxy-fuel mode: Pulverized Coal (PC) and Fluidized Bed (FB) combustors [1]. In oxy-fuel combustion, $\mathrm{SO}_{2}$ is a pollutant gas to take into consideration before $\mathrm{CO}_{2}$ transport and storage. In the process of $\mathrm{SO}_{2}$ removing, an additional unit is needed in PC boilers. However, in FB combustors the desulfurization process may be directly performed inside the boiler by supplying a Ca-based sorbent, this aspect being a relevant advantage compared to PC. The limestone, mainly composed of $\mathrm{CaCO}_{3}$, is currently one of the most used Ca-based sorbent in entire world to perform the desulfurization process due to its low cost and its high availability.

According to the equilibrium diagram of $\mathrm{CaCO}_{3}$ calcination reaction (R1) [2], which is represented in

Fig. 1, the temperature and $\mathrm{CO}_{2}$ partial pressure are important operating variables to define the behavior of the limestone. In conventional air combustion conditions, the $\mathrm{CO}_{2}$ concentration generated from coal combustion is relatively low (about 15 vol.\%) and thus the limestone sulfation is always performed in calcining conditions (R2) [3,4]. However, in oxy-fuel combustion conditions, the $\mathrm{CO}_{2}$ concentration existing in the boiler is much higher, ranging from 65 to 90 vol.\%, and therefore the limestone may operate in calcining (R2) or non-calcining conditions (R3) $[5,6]$.

$$
\begin{aligned}
\mathrm{CaCO}_{3} & \rightleftharpoons \mathrm{CaO}+\mathrm{CO}_{2} \\
\mathrm{CaO}+\mathrm{SO}_{2}+1 / 2 \mathrm{O}_{2} & \rightleftharpoons \mathrm{CaSO}_{4} \\
\mathrm{CaCO}_{3}+\mathrm{SO}_{2}+1 / 2 \mathrm{O}_{2} & \rightleftharpoons \mathrm{CaSO}_{4}+\mathrm{CO}_{2}
\end{aligned}
$$


One of the limiting characteristic of the limestone as Ca-based sorbent is its level of sulfation which seldom reaches full conversion. This means it is not possible to make use of the whole particle since the blockage of the outer pores occurs as $\mathrm{CaSO}_{4}$ is forming. It must be considered that the molar volume of $\mathrm{CaSO}_{4}$ is higher than that of the initial reactant, that is, $\mathrm{CaCO}_{3}$ or $\mathrm{CaO}$.

In previous studies on sulfation of Ca-based sorbents performed by the research group at oxy-fuel conditions in a thermogravimetric analyzer (TGA) [7] and in a batch FB reactor [8], it has been observed that the highest sulfation conversions are achieved in calcining conditions and the sulfation reaction is carried out in two steps, the former being faster than the latter. The first one is controlled by the diffusion of the reactant gas through the porous system of the particle until the blockage of the external pores is produced, and the second one by the diffusion of the reactant gas through the product layer according to the shrinking core model [9]. Several researchers [10, 11] found that the residual activity of the limestone, that is, the second reaction step, plays an important role in the sulfation process at long reaction times which are typical of the circulating fluidized bed combustors (CFBC). Therefore, the study of the evolution of the product layer formed during the sulfation process could be a key aspect to have an insight into the sulfation process.

On the other hand, at oxy-fuel operating conditions, an optimum temperature with respect to sulfur retention was found to be about $900-925{ }^{\circ} \mathrm{C}$ corresponding to calcining conditions [12]. Operating temperatures above $925{ }^{\circ} \mathrm{C}$ led to a decrease in the sulfur retention values. This fact suggests that the limestone particles undergo a loss of reactivity due to the sintering phenomena associated with the reactant solid [13], $\mathrm{CaO}$ or $\mathrm{CaCO}_{3}$, or the product layer, $\mathrm{CaSO}_{4}$. Anthony and Granatstein [14] reported another explanation based on the possibility of $\mathrm{CaSO}_{4}$ decomposition at high temperatures, leading to a release of $\mathrm{SO}_{2}$ and lower sulfur retention values. Those results were corroborated by de las Obras-Loscertales et al., (2014) during the operation in a continuous oxy-fuel bubbling FB combustor.

Most of the research studies about morphological properties of sulfated Ca-based sorbents have been carried out under conventional combustion conditions [11, 15, 16]. However, as a consequence of the 
very different conditions (regarding gas composition and temperature) existing in the oxy-fuel boiler, different morphological properties in the sorbents could be expected.

The main novelty of this work is focused on studying the morphological variations of the Ca-based sorbents during sulfation at oxy-fuel combustion conditions; especially the evolution with time of the external product layer of $\mathrm{CaSO}_{4}$ at different operating conditions. For this purpose, sulfated sorbent samples obtained in a TGA were analyzed by the Scanning Electronic Microscope (SEM) technique.

\section{EXPERIMENTAL SECTION}

\subsection{Materials}

The materials used as calcium sorbent for the SEM analysis were two Spanish Ca-based sorbents, one limestone and one dolomite, in a narrow particle size interval between 0.1 and $0.2 \mathrm{~mm}$. The sorbents were dry. The limestone used is mainly composed of $\mathrm{CaCO}_{3}$, whereas the dolomite is characterized by presenting a $\mathrm{Ca} / \mathrm{Mg}$ molar ratio close to one $(\mathrm{Ca} / \mathrm{Mg}=1.1)$.

Since Ca-based sorbents can be used for the sulfur retention in calcining or non-calcining conditions, it is essential to know the main physical properties of raw and calcined sorbent. Table 1 shows the chemical composition and the physical properties of the sorbents used. Chemical composition was determined by inductively coupled plasma (ICP) analysis. Apparent density and porosity were determined by Helium pycnometry and mercury intrusion, respectively. As can be seen, these properties undergo great changes depending on whether the sorbent is raw, semi-calcined (dolomite case) or calcined. These variations are related to the different molar volume of the compounds $\left(\mathrm{MgCO}_{3}\right.$ or $\mathrm{MgO}$ and $\mathrm{CaCO}_{3}$ or $\left.\mathrm{CaO}\right)$. In all the cases, raw sorbents presented a high crystallization level which involves low porosity. During the calcination stage the sorbents develop a high porosity because the $\mathrm{CaO}$ molar volume is lower than that of $\mathrm{CaCO}_{3}$. Later, the porosity decreased during sulfation process because the $\mathrm{CaSO}_{4}$ presented a higher molar volume than the $\mathrm{CaO}$.

\subsection{Characterization methodology}


The sulfated sorbent samples were prepared in a TGA, Setaram TGC-85 type, described elsewhere [7]. The sample holder was a wire mesh platinum basket ( $8 \mathrm{~mm}$ diameter, $2 \mathrm{~mm}$ height). The reacting gas mixture containing $\mathrm{SO}_{2}, \mathrm{CO}_{2}, \mathrm{O}_{2}$ and $\mathrm{N}_{2}$, was controlled by specific electronic mass-flow controllers and it was introduced at the bottom of the reaction tube. In calcining conditions, the sorbents underwent two stages, calcination and sulfation, whereas in non-calcining conditions the sulfation was carried out over the raw sorbent. For each run, $30 \mathrm{mg}$ of sample was put into the basket and rapidly introduced into the TGA reactor at the desired temperature and gas composition $\left(\mathrm{N}_{2}+\mathrm{CO}_{2}+\mathrm{O}_{2}\right)$. $\mathrm{SO}_{2}$ was introduced after weight stabilization of calcined or non-calcined sample. The total gas flow was $10 \mathrm{lN} / \mathrm{h}$ to assure that neither external mass transfer nor inter-particle diffusion were affecting the sulfation reaction rate. The interval of temperature ranged from 800 to $975{ }^{\circ} \mathrm{C}$, the $\mathrm{CO}_{2}$ concentration from 15 to 80 vol.\%, and the $\mathrm{O}_{2}$ concentration from 4 to 40 vol.\%. The $\mathrm{SO}_{2}$ concentration was kept constant at 3000 vppm in all tests.

The sulfation conversion of the sorbents along time in both calcining $\left(\mathrm{X}_{\mathrm{s} \text {,cal }}\right)$ and non-calcining conditions $\left(\mathrm{X}_{\mathrm{s} \text {,non-cal }}\right)$ was calculated from the sample mass variation registered by the TGA as follow:

$$
\begin{aligned}
& \mathrm{X}_{\mathrm{s}, \mathrm{cal}}(\mathrm{t})=\frac{\mathrm{W}(\mathrm{t})-\mathrm{W}_{\mathrm{CaO}}}{\mathrm{W}_{\mathrm{CaSO}_{4}}-\mathrm{W}_{\mathrm{CaO}}} \\
& \mathrm{X}_{\mathrm{s}, \text { non-cal }}(\mathrm{t})=\frac{\mathrm{W}(\mathrm{t})-\mathrm{W}_{\mathrm{CaOO}_{3}}}{\mathrm{~W}_{\mathrm{CaSO}_{4}}-\mathrm{W}_{\mathrm{CaCO}_{3}}}
\end{aligned}
$$

being $\mathrm{W}(t)$ the mass of the sample at each time, $\mathrm{W}_{\text {СаO }}$ the initial mass of $\mathrm{CaO}, \mathrm{W}_{\text {Сасоз }}$ the initial mass of $\mathrm{CaCO}_{3}$, and $\mathrm{W}_{\mathrm{CasO4}}$ the mass of the sample assuming total conversion to $\mathrm{CaSO}_{4}$.

The sulfated samples were kept in a desiccator to avoid hydration before analysis.

To analyse the internal section of the particles, particles were embedded in epoxy resin, cured overnight, cut and polished before SEM characterization. The morphology of the sorbents was analysed in a Scanning Electron Microscope (SEM) ISI- DS - 130 coupled to an ultra-thin window PGT Prism detector for energy dispersive X-ray (EDX). 


\section{RESULTS AND DISCUSSION}

The effect of temperature (from 800 to $975{ }^{\circ} \mathrm{C}$ ), $\mathrm{CO}_{2}$ concentration (from 15 to 80 vol.\%), and reaction times (15 min to 24 hours) on the sulfation process were analysed in a TGA to cover the possible conditions existing in a oxy-fuel FB combustor [17]. To follow the evolution with time of the $\mathrm{CaSO}_{4}$ product layer, samples sulphated at different reaction times were obtained.

\subsection{Effect of reaction time on product layer}

The mean residence time of solids in CFBCs is an intrinsic variable of this type of boilers which can range up to 10-20 hours for particles just above $200 \mu \mathrm{m}$ [18]. In addition, it has been demonstrated that the residual activity of the sorbent after blocking the outer pores during the sulfation process may be significant $[7,10,11]$. Therefore, it is expected that an increased residence time of the solids leads to higher sulfur retention values.

To get an insight into the evolution of the $\mathrm{CaSO}_{4}$ product layer with respect to the residence time of the solids in the combustor, sulfated samples at different reaction times were prepared in the TGA and analyzed by SEM technique. These samples correspond to the points represented in the sulfation conversion curves showed in Fig. 2 for limestone and dolomite under calcining and non-calcining conditions. Fig.s 3 and 4 illustrate the evolution of the external and internal surface of sulfated particles of Granicarb limestone at different reaction times, both in calcining and non-calcining conditions, respectively.

Fig. 3A shows how the structure of the limestone is being closed during the first step of the sulfation reaction and therefore for short reaction times, 15 minutes, the product layer of $\mathrm{CaSO}_{4}$ is not well defined because the external pores are not completely blocked. Subsequently in next picture (Fig. 3B) it can be seen that the $\mathrm{CaSO}_{4}$ product layer has plugged the external pores and has completely covered the outer part of the particle indicating that the second reaction step has already started. This second step is characterized by producing a decrease in the sorbent reactivity whose sulfation pattern corresponds to the Shrinking Core Model (SCM) [9]. Likewise, the change of the mechanism of 
reaction, between first and second step, can be graphically identified with the change in the slope of the sulfation curve obtained in TGA tests (see Fig. 2). Subsequently, as the sulfation reaction is proceeding, a continuous increase in the thickness of the $\mathrm{CaSO}_{4}$ product layer and in the grain size of $\mathrm{CaSO}_{4}$ were observed (Fig. 3C). So, for long reaction times, the thickness of the product layer might reach values near the radio of the limestone particle as it is shown in Fig. 3D. In addition, in this picture, two different structures of $\mathrm{CaSO}_{4}$ product layer were observed.

The first one, corresponding to the inner part, was composed of small $\mathrm{CaSO}_{4}$ crystals. The second one, corresponding to the outer part, was composed of $\mathrm{CaSO}_{4}$ crystals with honeycomb-shaped structure. The space limitations as a consequence of the higher molar volume of $\mathrm{CaSO}_{4}$ compared to $\mathrm{CaO}$ in the external surface of the particles make that the $\mathrm{CaSO}_{4}$ product layer trend to grow outwards to form this honeycomb-shaped structure. Moreover, making a comparison between $\mathrm{CaO}$ and $\mathrm{CaSO}_{4}$ grains, a significant increase in the grain size is observed during the sulfation stage not only due to the different molar volume but also to the agglomeration or coalescence of several grains.

In non-calcining conditions (see Fig. 4), the $\mathrm{CaCO}_{3}$ grains are not well-distinguished in the inner part of the particle and exhibited a more compact appearance. However, some similarities with respect to the calcining conditions were observed, i.e. the sulfation pattern coincided with the SCM and an external honeycomb-shaped $\mathrm{CaSO}_{4}$ product layer was developed. It should be remarked that this structure is formed at shorter reaction times as a consequence of the higher space limitations in the external layer of the limestone particles.

Hajaligol et al. [19] and Snow et al. [20] reported that the $\mathrm{CO}_{2}$ released outside from direct sulfation reaction was capable of creating preferential ways which provided higher porosity and high sulfation conversion. Nevertheless, based on the SEM images taken in this work, negligible differences in the $\mathrm{CaSO}_{4}$ product layer between calcining and non-calcining conditions were detected.

Regarding unreacted core at calcining conditions, previous studies found that $\mathrm{CaO}$ sintering produced important variations in sorbent structure [21]. This phenomenon affects sorbent reactivity especially in those processes where the time scales of sorbent decomposition and reaction are similar, e.g., the 
calcination-sulfation in furnace sorbent injection processes (particle sizes below $80 \mu \mathrm{m}$ and short reaction times, below minutes) [22]. In non-calcining conditions, de Diego et al. [23] observed that $\mathrm{CaCO}_{3}$ sintering affected reaction rate during sulfidation at typical gasification conditions and particle sizes used in FB, but no relevant changes were observed in the morphological analysis of the particles. In a similar way, the morphological analysis of the unreacted core carried out in this work revealed negligible variations in the internal structure of the sorbent during long sulfation times despite their possible effect on reactivity.

In addition, the morphological changes suffered by dolomite in the product layer were masked due to the existence of MgO which provide an extra porosity to the particle (MgO behaves as inert solid during the sulfation process) (see Fig. 5). Previous studies demonstrated that dolomites are able to reach high sulfation conversions, near 1 with respect to $\mathrm{Ca}$ content, both in calcining and noncalcining conditions during oxyfuel combustion in fluidized beds [24], as observed in Fig. 3. The no space limitation as a consequence of the extra porosity avoided the honeycomb-shaped structure formation at any operating condition, even at high sulfation conversion. This characteristic was also maintained at semi-calcining conditions $\left(\mathrm{CaCO}_{3}-\mathrm{MgO}\right)$.

\subsection{Effect of temperature on the product layer}

As stated above, temperature is an important variable in the sulfation process because depending on the $\mathrm{CO}_{2}$ partial pressure used, the limestone will be sulfated under calcining or non-calcining conditions. This variable will highly affect the sulfation level reached by the sorbent. In addition, temperature may have a direct influence on morphological and structural properties of the sorbent. To analyze the influence of the sintering phenomenon in the $\mathrm{CaSO}_{4}$ product layer, several samples sulfated at different temperatures at long reaction times (24 hours) were studied. The SEM images of the external surface are shown in Fig. 6. Considering the high sulfation level of the particles, negligible differences for samples sulfated at temperatures below $900{ }^{\circ} \mathrm{C}$ and typical honeycombshape structure at the external layer were detected. This structure undergoes a slight change from 900 
to $950{ }^{\circ} \mathrm{C}$ but the most relevant change was observed in the sulfated sorbent at $975{ }^{\circ} \mathrm{C}$. Some researchers [25-27] found that high temperatures led to the sintering phenomenon of the sorbents decreasing their sulfation capacity. Therefore, this effect seems to be one of those responsible for decreasing the sorbent sulfation conversion at temperatures above $900{ }^{\circ} \mathrm{C}$ obtained in TGA [7]. However, Anthony and Granatstein, [14] and de las Obras-Loscertales et al. [24] reported that the existence of reducing conditions in localized parts of the bed are capable of producing the reverse sulfation reaction at high temperatures during operation in FB combustors. This phenomenon together with the sorbent sintering could be responsible for the optimum temperature found during the sulfur retention in oxy-fuel FB combustors, $900-925^{\circ} \mathrm{C}$ (see Fig. 6).

Finally, it must be considered that the morphology of the calcium sulfate layer and the conversion degree can be modified by attrition phenomena [28, 29] and the presence of fuel-ashes [14] under real FB combustion conditions.

\subsection{Effect of $\mathrm{CO}_{2}$ concentration on the product layer.}

Oxy-fuel combustion is based on burning the fuel with a mix of oxygen and a $\mathrm{CO}_{2}$-rich recirculated flue gas stream in order to control the operating temperature in the combustor. Therefore, the $\mathrm{CO}_{2}$ concentration is a key factor to be considered in the process when comparing with conventional air combustion process. As it was stated, Ca-based sorbent may operate under calcining or non-calcining conditions. Nevertheless, there is no an agreement with respect to the effect of $\mathrm{CO}_{2}$ concentration on sulfation reaction. Some researchers found that the sulfation conversion was higher under noncalcining than under calcining conditions $[19,20]$. They argued that the $\mathrm{CaSO}_{4}$ product layer formed under non-calcining conditions was more porous than in calcining conditions due to the $\mathrm{CO}_{2}$ flow released during the direct sulfation reaction (R3). However, Hu et al. [30] disagreed with this assumption since they consider that porosity is unlikely to be created from a diffusional flow of $\mathrm{CO}_{2}$. Likewise, other authors [31-33] have observed that high $\mathrm{CO}_{2}$ partial pressures reduce the sulfation reaction rate under certain operating conditions. 
To analyze the influence of the $\mathrm{CO}_{2}$ partial pressure on the $\mathrm{CaSO}_{4}$ layer formed around the particles, SEM photographs of highly sulfated limestone at different $\mathrm{CO}_{2}$ concentrations (15, 65 and 80 vol.\%) were studied, which corresponded to both non-calcining and calcining conditions. As can be seen in Fig. 7, the outer surface of the particles exhibits similar structure and is not affected by the concentration of $\mathrm{CO}_{2}$ at each specific condition, calcining or non-calcining. These results corroborated previous studies carried out by the research group $[7,8]$ where it was found that the main effect of $\mathrm{CO}_{2}$ concentration on the sulfation process was associated with the fact of defining calcining or non-calcining conditions. An increase in $\mathrm{CO}_{2}$ concentration shifted the temperature of $\mathrm{CaCO}_{3}$ decomposition to higher values. However, once calcining or non-calcining conditions were reached, the effect of $\mathrm{CO}_{2}$ could be considered negligible.

\section{CONCLUSIONS}

Morphological characterization of two Ca-based sorbents, one limestone and one dolomite, during the sulfation process was carried out at conditions kind of oxy-fuel CFB combustion. A TGA was employed to obtain the sulfated samples. The sorbent structure and the evolution of $\mathrm{CaSO}_{4} \mathrm{product}$ layer were analyzed by SEM-EDX technique.

Two different structures of $\mathrm{CaSO}_{4}$ product layer were observed during limestone sulfation. The first one, corresponding to the inner part of particles, was composed of small $\mathrm{CaSO}_{4}$ crystals. In contrast, the space limitations as a consequence of the higher molar volume of $\mathrm{CaSO}_{4}$ compared to $\mathrm{CaO}$ in the external surface of the particles make that the $\mathrm{CaSO}_{4}$ product layer trend to grow outwards to form a honeycomb-shaped structure. This structure was observed both in calcining and non-calcining conditions.

The honeycomb-shaped structure was never found during dolomite sulfation because the extra porosity developed during $\mathrm{MgCO}_{3}$ calcination lead to the lack of space limitations. In this case, high sulfation conversions were reached in semi-calcining $\left(\mathrm{CaCO}_{3}-\mathrm{MgO}\right)$ and calcining $(\mathrm{MgO} . \mathrm{CaO})$ conditions. 
The morphological changes in the sulfated particles were analyzed in the whole range of temperatures from 850 to $975{ }^{\circ} \mathrm{C}$. The honeycomb-shaped structure was observed at all temperatures, except to 975 ${ }^{\circ} \mathrm{C}$, as a consequence of the severe sintering effect observed at values above $950{ }^{\circ} \mathrm{C}$.

Eventually, the external surface of limestone particles was not affected by the $\mathrm{CO}_{2}$ concentration in both calcining and non-calcining conditions.

\section{Acknowledgment}

This work has been supported by The Spanish Ministry of Science and Innovation (MICINN, Project: CTQ2008-05399/PPQ) and by the European Regional Development Fund (ERDF). M. de las ObrasLoscertales thanks to MICINN for the F.P.I. fellowship and A. Rufas to CSIC for the JAE fellowship.

\section{References}

[1] Scheffknecht G, Al-Makhadmeh L, Schnell U, Maier J. Oxy-fuel coal combustion—A review of the current state-of-the-art. Int J Greenhouse Gas Control 2011;5:S16-S35.

[2] Barin I. Thermochemical data of pure substances.1989. VCH, Weinheim, Germany.

[3] Adánez J, García-Labiano F, Gayán P. Sulfur retention in AFBC. Modelling and sorbent characterization methods. Fuel Process Technol 1993;36:73-9.

[4] García-Labiano F, Abad A, de Diego LF, Gayán P, Adánez J. Calcination of calcium-based sorbents at pressure in a broad range of $\mathrm{CO}_{2}$ concentrations. Chem Eng Sci 2002;57:2381-93.

[5] Fuertes AB, Velasco G, Fernandez MJ, Alvarez T. Analysis of the direct sulfation of calcium carbonate. Thermochim Acta 1994;242:161-72.

[6] Fuertes AB, Velasco G, Fuente E, Alvarez T. Study of the direct sulfation of limestone particles at high $\mathrm{CO}_{2}$ partial pressures. Fuel Process Technol 1994;38:181-92.

[7] García-Labiano F, Rufas A, de Diego LF, de las Obras-Loscertales M, Abad A, Gayán P, Adánez J. Calcium-based sorbents behaviour during sulphation at oxy-fuel fluidised bed combustion conditions. Fuel 2011;90:3100-8. 
[8] de Diego LF, de las Obras-Loscertales M, García-Labiano F, Rufas A, Abad A, Gayán P, Adánez J. Characterization of a limestone in a batch fluidized bed reactor for sulfur retention under oxyfuel operating conditions. Int. J. Greenhouse Gas Control 2011;5:1190-8.

[9] de las Obras-Loscertales M, de Diego LF, García-Labiano F, Rufas A, Abad A, Gayán P, Adánez J. Modelling of limestone sulfation for typical oxy-fuel fluidized bed combustion conditions. Energy Fuels 2013;27:2266-74.

[10] Abanades JC, de Diego LF, García-Labiano F, Adánez J. Residual activity of sorbent particles with a long residence time in a CFBC. AIChE J 2003;46:1888-93.

[11] Abanades JC, Anthony EJ, García-Labiano F, Jia L. Progress of sulfation in highly sulfated particles of lime. Ind Eng Chem Res 2003;42:1840-4.

[12] de Diego LF, Rufas A, García-Labiano F, de las Obras-Loscertales M, Abad A, Gayán P, Adánez J. Optimum temperature for sulphur retention in fluidised beds working under oxy-fuel combustion conditions. Fuel 2013;114:106-13.

[13] Mahuli SK, Agnihotri R, Jadhav R, Chauk S, Fan LS. Combined calcination, sintering and sulfation model for $\mathrm{CaCO}_{3}-\mathrm{SO}_{2}$ reaction. AIChE J 1999;45:367-82.

[14] Anthony EJ, Granatstein DL. Sulfation phenomena in fluidized bed combustion systems. Prog Energ Combust Sci 2001;27:215-36.

[15] Laursen K, Duo W, Grace JR, Lim J.Sulfation and reactivation characteristics of nine limestones. Fuel 2000;79:153-63.

[16] Kenakkala T, Kokkonen P, Kuoppala H. Reaction mechanism studies in limestone sulphation using SEM-EDS technique. Thermochim Acta 1991;175:79-89.

[17] Lyngfelt A, Leckner B. Residence time distribution of sorbent particles in a circulating fluidised bed boiler. Powder Technol 1992;70:285-92.

[18] Mattison T, Lyngfelt A. A sulfur capture model for circulating fluidized-bed boilers. Chem Eng Sci 1998;53:1163-73. 
[19] Hajaligol MR, Longwell JP, Sarofim AF. Analysis and modeling of the direct sulfation of calcium carbonate. Ind Eng Chem Res 1988;27:2203-10.

[20] Snow MJH, Longwell JP, Sarofim AF. Direct sulfation of calcium carbonate. Ind Eng Chem Res 1988;27:268-73.

[21] García-Labiano F, Abad A, de Diego LF, Gayán P, Adánez J. Calcination of calcium-based sorbents at pressure in a broad range of $\mathrm{CO}_{2}$ concentrations. Chem Eng Sci 2002;57:2381-93.

[22] Adánez J, García-Labiano F, Fierro V. Modelling for the high-temperature sulphation of calcium-based sorbents with cylindrical and plate-like pore geometries. Chem Eng Sci 2000;55:3665-83.

[23] de Diego LF, García-Labiano F, Adánez J. Factors affecting the $\mathrm{H}_{2} \mathrm{~S}$ reaction with noncalcined limestones and half-calcined dolomites. Energy Fuel 1999;13:146-53.

[24] de las Obras-Loscertales M, de Diego LF, García-Labiano F, Rufas A, Abad A, Gayán P, Adánez J. Sulfur retention in an oxy-fuel bubbling fluidized bed combustor: Effect of coal rank, type of sorbent and $\mathrm{O}_{2} / \mathrm{CO}_{2}$ ratio. Fuel 2014;137:384-92.

[25] Illerup JB, Dam-Johansen K, Lunden K. High-temperature reaction between sulphur dioxide and limestone - VI. The influence of high pressure. Chem Eng Sci 1993;48:2151-7.

[26] Zevenhoven CAP, Yrjas KP, Hupa MM. Sulfur dioxide capture under PFBC conditions: the influence of sorbent particle structure. Fuel 1998;77:285-92.

[27] Zevenhoven CAP, Yrjas KP, Hupa MM. Product layer development during sulfation and sulfidation of uncalcined limestone particles at elevated pressures. Ind Eng Chem Res 1998;37, 2639-46.

[28] Scala F, Salatino P, Boerefijn R, Ghadiri M. Attrition of sorbents during fluidized bed calcination and sulphation. Powder Technol 2000;107:153-67.

[29] Montagnaro F, Piero Salatino P, Scala F. The influence of temperature on limestone sulfation and attrition under fluidized bed combustion conditions. Exp Thermal Fluid Sci 2010;34:352-8. 
[30] Hu G, Dam-Johansen K, Wedel S, Hansen JP. Review of the direct sulfation reaction of limestone. Prog Energ Combust Sci 2006;32:386-407.

[31] Ulerich NH, Newby RA, Keairns DL. A thermogravimetric study of the sulfation of limestone and dolomite - prediction of pressurized and atmospheric fluidized-bed desulfurization. Thermochim Acta 1980;36:1-16.

[32] Tullin C, Ljungstroem E. Reaction between calcium carbonate and sulfur dioxide. Energy Fuels 1989;3:284-7.

[33] Hu G, Dam-Johansen K, Wedel S, Hansen JP. Direct sulfation of limestone. AIChE J 2007;53:948-60. 


\section{TABLES AND FIGURES}

Table 1. Chemical analysis and physical properties of the sorbents.

Limestone

Granicarb
Dolomite

Sierra Arcos

\section{Composition (\% wt)}

$\mathrm{CaCO}_{3}$

97.1

52.5

$\mathrm{MgCO}_{3}$

0.2

40.5

$\mathrm{Na}_{2} \mathrm{O}$

1.1

$<0.1$

$\mathrm{SiO}_{2}$

$<0.1$

3.8

$\mathrm{Al}_{2} \mathrm{O}_{3}$

$<0.1$

1.7

$\mathrm{Fe}_{2} \mathrm{O}_{3}$

$<0.1$

0.6

\section{Apparent density $\left(\mathrm{kg} / \mathrm{m}^{3}\right)$}

Raw $\left(\mathrm{CaCO}_{3}\right)$

2573

2512

Semi-calcined $\left(\mathrm{CaCO}_{3} \cdot \mathrm{MgO}\right)^{*}$

Calcined $(\mathrm{CaO}) * *$

1578

1454

Porosity (\%)

Raw $\left(\mathrm{CaCO}_{3}\right)$

9.5

Semi-calcined $\left(\mathrm{CaCO}_{3} \cdot \mathrm{MgO}\right) *$

30.6

Calcined $(\mathrm{CaO})^{* *}$

49.0

51.7

* Calcined in $\mathrm{CO}_{2}$ atmosphere at $850{ }^{\circ} \mathrm{C}$ during 10 minutes.

** Calcined in $\mathrm{N}_{2}$ atmosphere at $900{ }^{\circ} \mathrm{C}$ during 10 minutes 


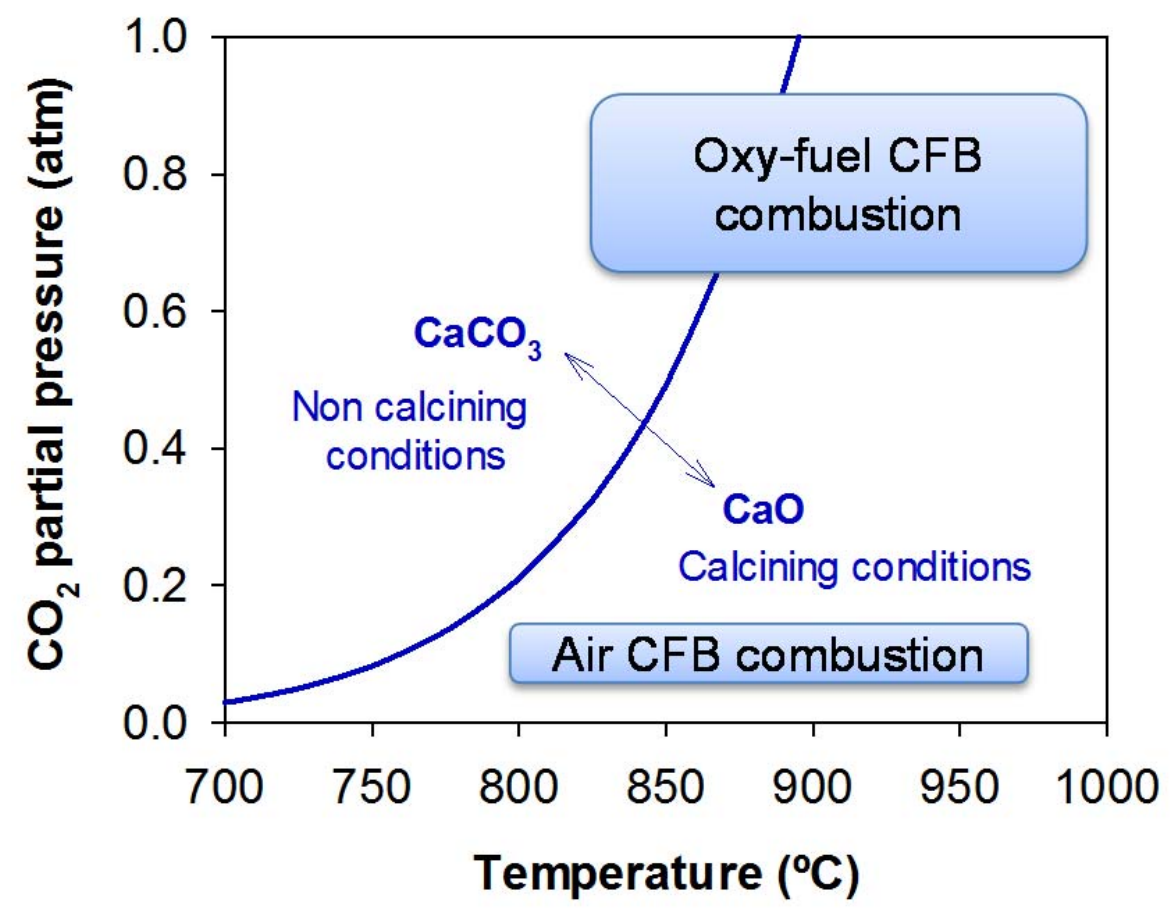

Fig. 1. Thermodynamic equilibrium curve of $\mathrm{CaCO}_{3}$ calcination 


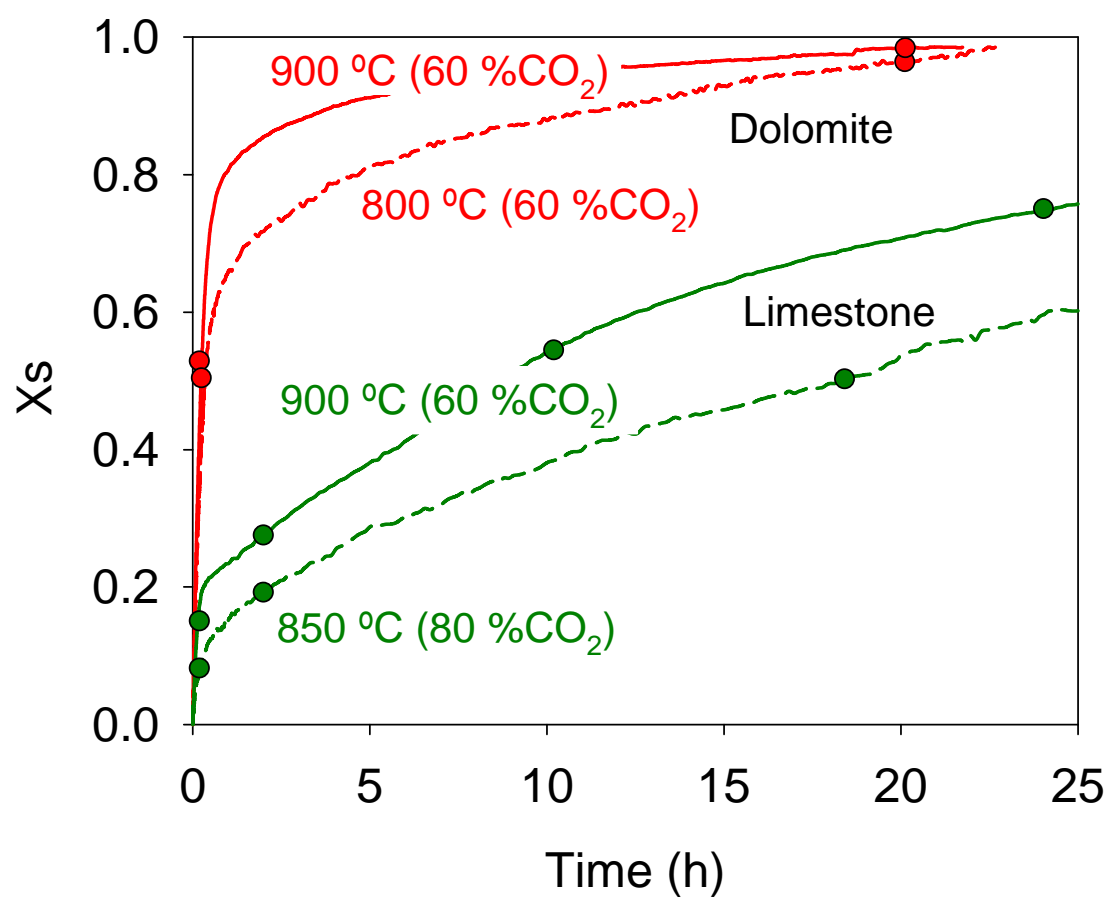

Fig. 2. Sulfation conversion curves in TGA. Symbols represent sulfated samples used for SEM characterization. _ calcining and - - - non-calcining conditions. $\mathrm{SO}_{2}=3000 \mathrm{vppm}$. dp=0.1-0.2 mm. 
External surface
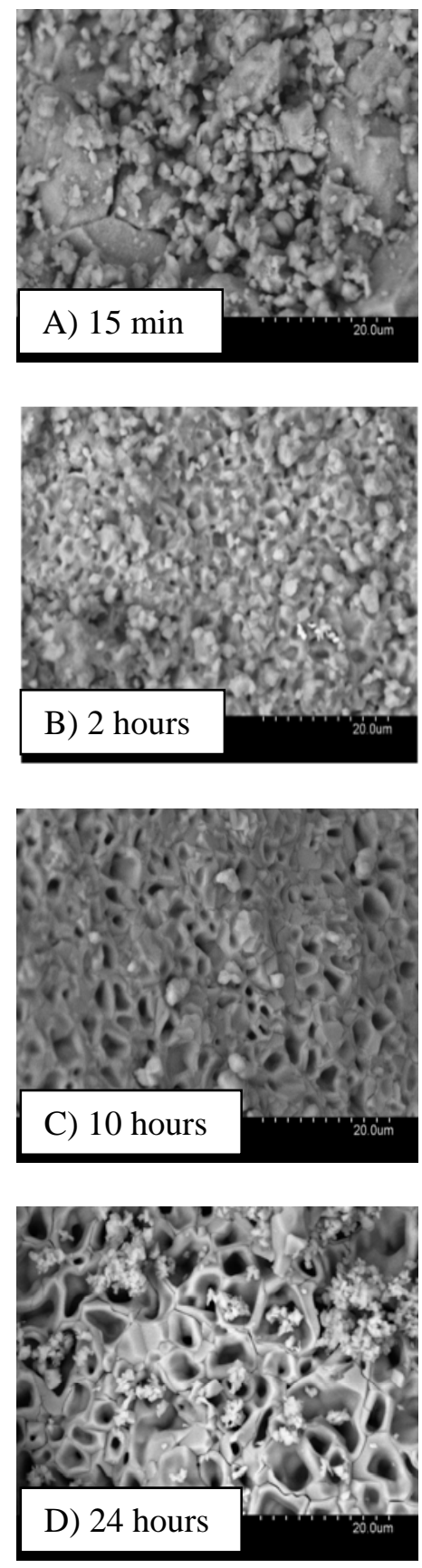

Internal surface
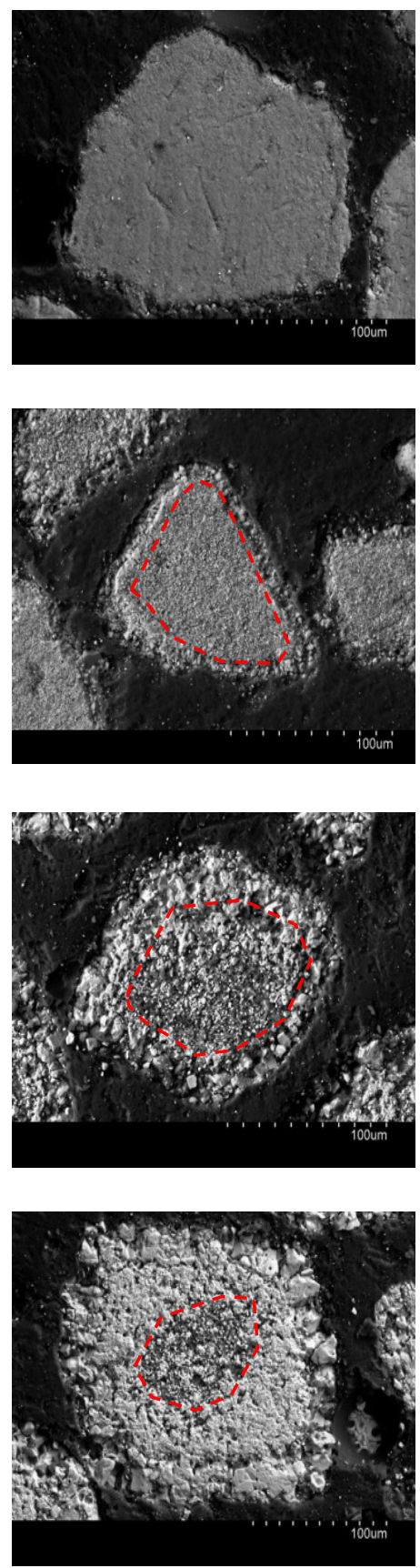

$\mathrm{CaSO}_{4}$ product layer
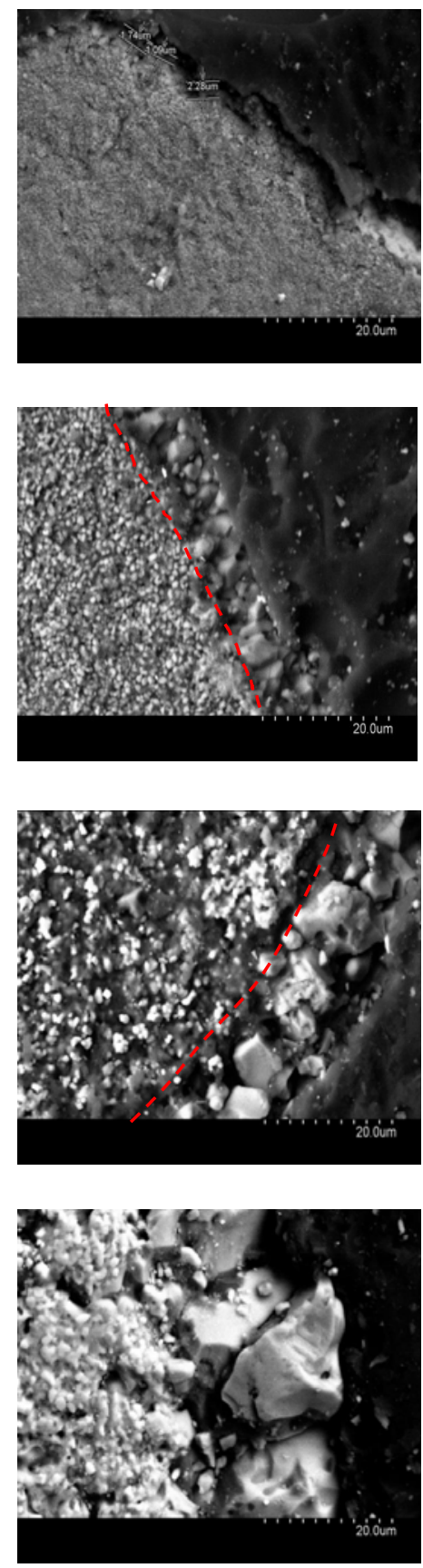

Fig. 3. SEM images of external and internal surface of Granicarb limestone in calcining conditions at different reaction times. $900{ }^{\circ} \mathrm{C}, 60 \% \mathrm{CO}_{2}, 3000 \mathrm{ppm} \mathrm{SO}$, dp= 0.1-0.2 mm. 
External surface
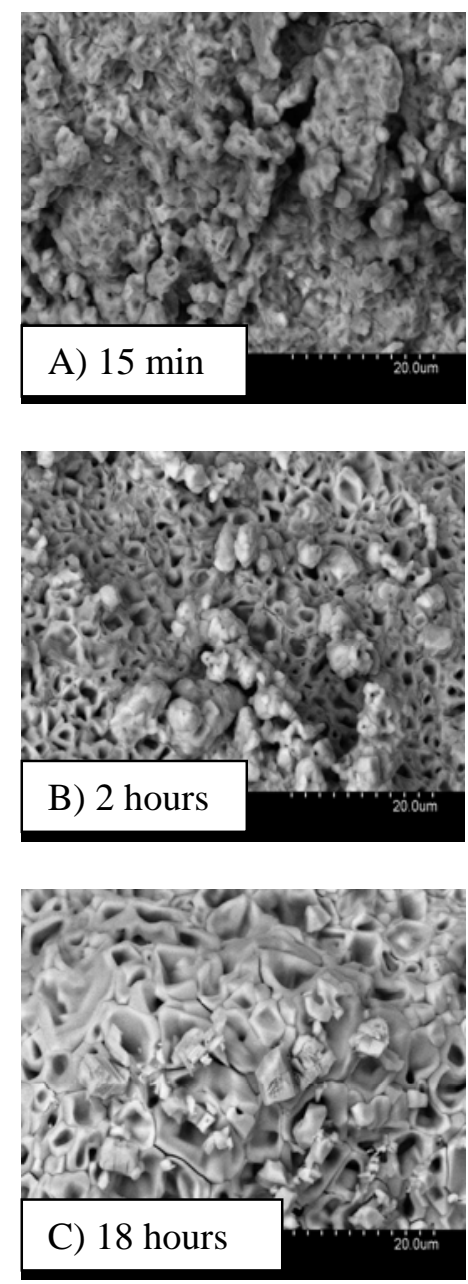

Internal surface
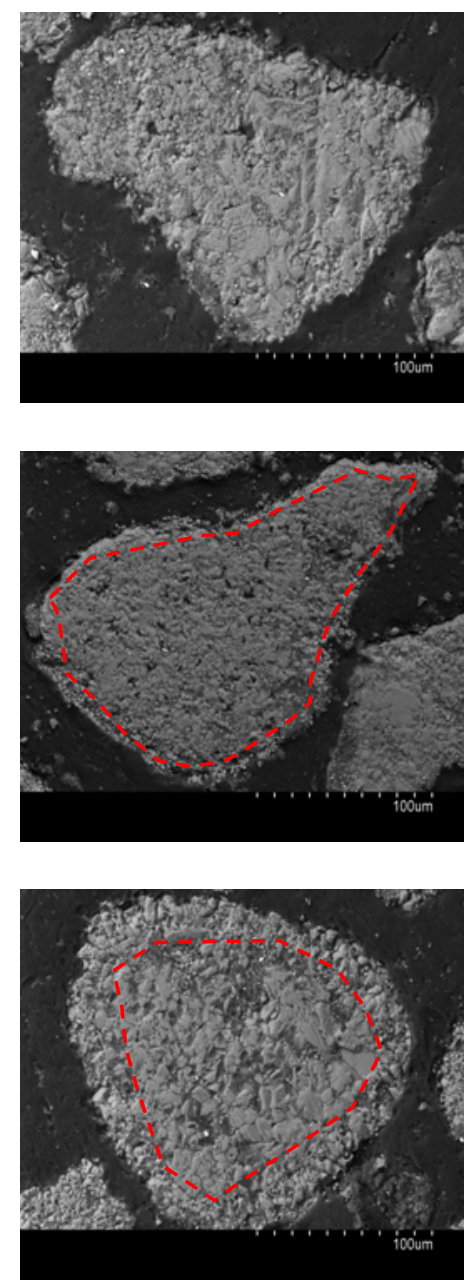

$\mathrm{CaSO}_{4}$ product layer
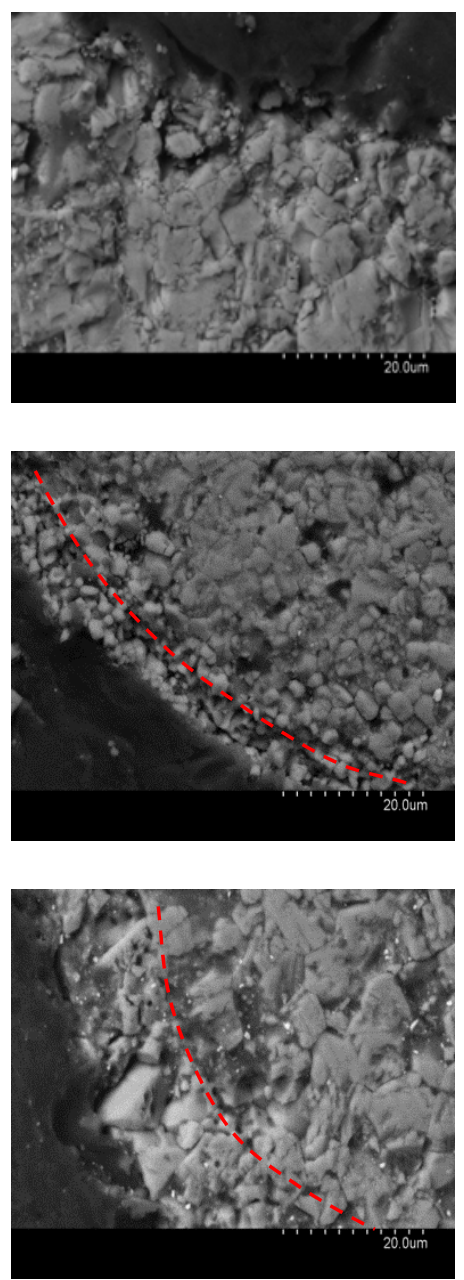

Fig. 4. SEM images of the external and internal surface of Granicarb limestone in noncalcining conditions at different reaction times. $850{ }^{\circ} \mathrm{C}, 80 \% \mathrm{CO}_{2}, 3000 \mathrm{ppm} \mathrm{SO}$, dp= 0.1-0.2 mm. 
Direct sulfation

2 hours

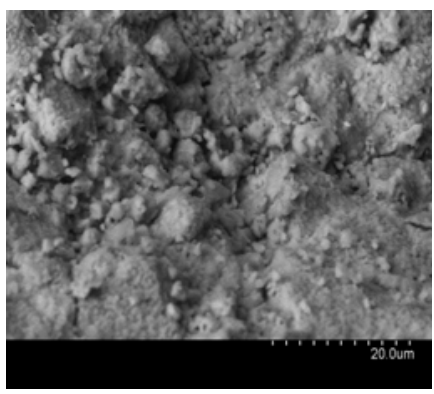

20 hours

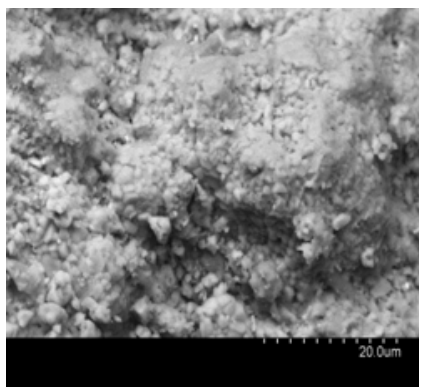

Indirect sulfation

2 hours

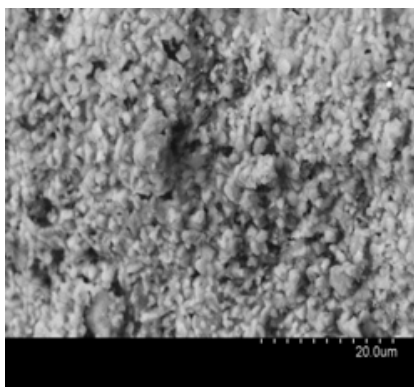

20 hours

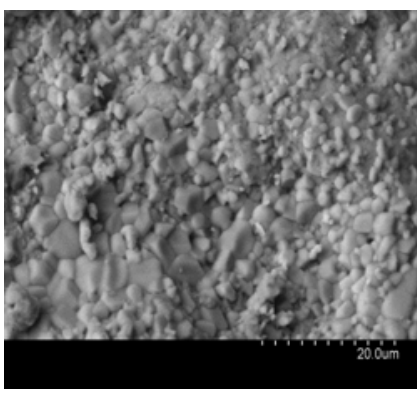

Fig. 5. SEM images of external $\mathrm{CaSO}_{4}$ product layer of Sierra de Arcos dolomite at different reaction times. $60 \% \mathrm{CO}_{2}, 3000 \mathrm{ppm} \mathrm{SO}$, dp= 0.1-0.2 mm. Direct sulfation $\left(800^{\circ} \mathrm{C}\right)$ and indirect sulfation $(900$ $\left.{ }^{\circ} \mathrm{C}\right)$. 

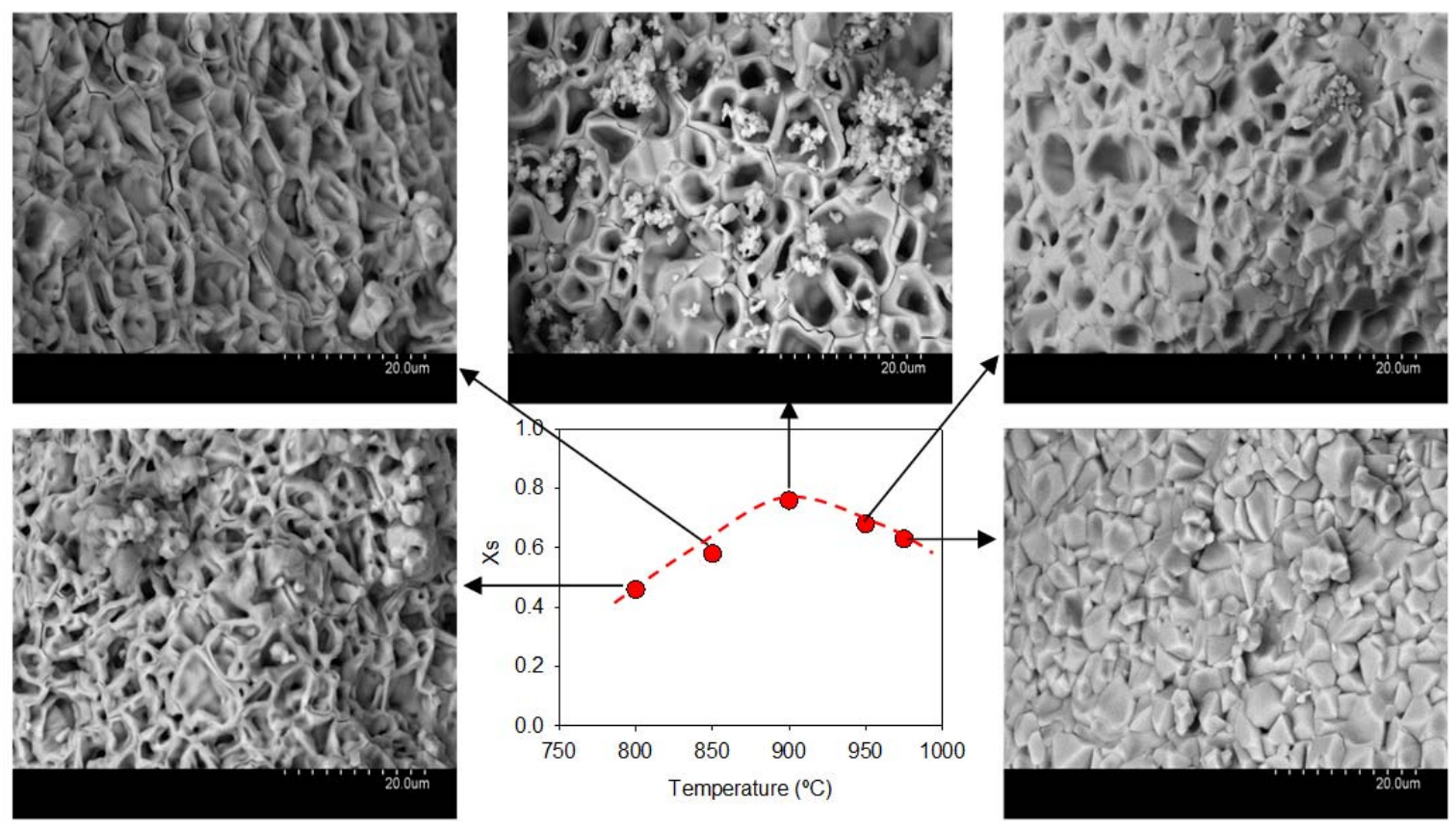

Fig. 6. SEM images of external surface of Granicarb limestone sulfated at different temperatures for 24 hours. $60 \% \mathrm{CO}_{2}, 3000 \mathrm{ppm} \mathrm{SO}_{2}$, dp= 0.1-0.2 mm. 
Indirect sulfation

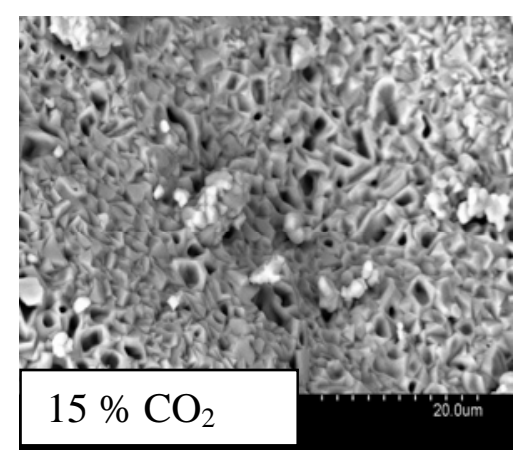

Direct sulfation
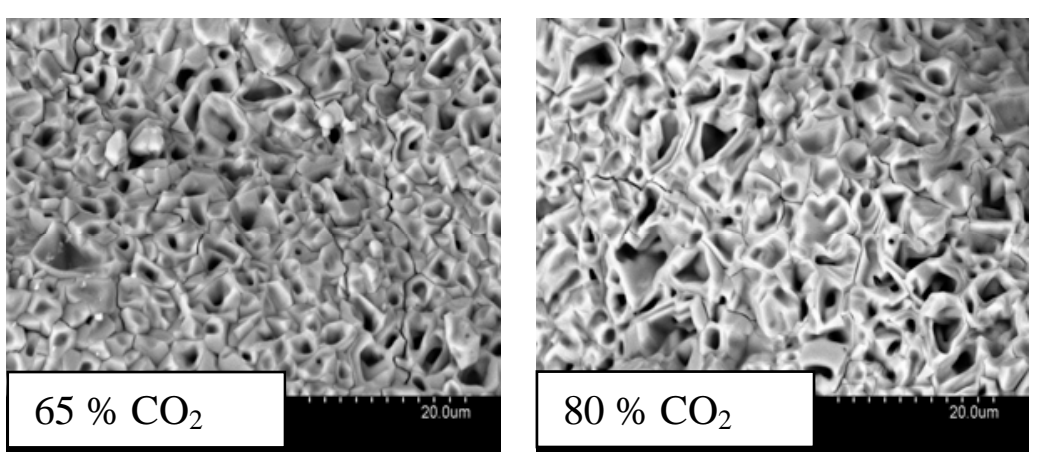

Fig. 7. SEM images of the external surface of Granicarb sulfated limestone for 24 hours at different $\mathrm{CO}_{2}$ concentrations. $850{ }^{\circ} \mathrm{C}, 3000 \mathrm{ppm} \mathrm{SO}$, dp= 0.1-0.2 mm. 